Article

\title{
Corporate Responsibility in India: Academic Perspectives on the Companies Act 2013
}

\author{
Manfred Max Bergman 1,2,*(D), Zinette Bergman ${ }^{1,3}{ }^{(\mathbb{D}}$, Yael Teschemacher ${ }^{1}$, Bimal Arora ${ }^{4}(\mathbb{D}$, \\ Divya Jyoti ${ }^{4}$ and Rijit Sengupta ${ }^{5}$ \\ 1 Department of Social Sciences, University of Basel, Basel 4051, Switzerland; \\ zinette.bergman@unibas.ch (Z.B.); yael.teschemacher@unibas.ch (Y.T.) \\ 2 Guest Faculty Member at the Mendoza College of Business, University of Notre Dame, South Bend, \\ IN 46556, USA \\ 3 Visiting Scholar at the Department of Political Science, Texas A\&M University, College Station, \\ TX 77840, USA \\ 4 Aston Business School, Aston University, Birmingham B4 7ET, UK; b.arora1@aston.ac.uk (B.A.); \\ jyotidi@aston.ac.uk (D.J.) \\ 5 Centre for Responsible Business, New Delhi 110067, India; rijit@c4rb.in \\ * Correspondence: max.bergman@unibas.ch
}

Received: 9 August 2019; Accepted: 22 October 2019; Published: 25 October 2019

check for updates

\begin{abstract}
Developing prosperous and inclusive societies requires a reformulation of the business-society nexus toward sustainability. This means that all economically motivated behaviors of firms also need to consider their social and environmental impact, and all social and environmental policies their impact on the business sector and the economy. With the Companies Act 2013, the Indian government adopted a legislative approach to reconfigure the business-society nexus. Mandating what has been considered discretionary elicited an extensive academic debate. To study this India-specific political corporate social responsibility (CSR), we employ Content Configuration Analysis on 70 local and international English-language book chapters, research articles, reports, reviews, and expert commentaries published between 2013 and 2019 to develop a typology of the advantages and disadvantages associated with the Companies Act 2013. Among a large number of positions for and against the Act, we find that arguments extolling its advantages concurrently appear as disadvantages in other texts. This paradox is indicative of the difficulties of satisfying stakeholder expectations, as well as the complexities corporate responsibility programs face in India. Nonetheless, CSR as a policy tool allows the Indian government to instrumentalize the growing success of the business sector to address local and national needs and expectations. By systematizing the opportunities and challenges associated with the Companies Act 2013, we show how, similar to China, context and culture influence India's socioeconomic development trajectory beyond the conventional market economy canon. Our analyses reveal how advantages and disadvantages are frequently connected to multiple stakeholders, including the government, business, and society. We conclude by highlighting the contribution this study makes to the field of political CSR.
\end{abstract}

Keywords: India; Companies Act 2013; business-society nexus; corporate social responsibility; Content Configuration Analysis; political CSR

We have seen the business sector generating wealth and value for the shareholders in the last sixty years, but simultaneously we also have the problems of poverty, unemployment, illiteracy, malnutrition, etc. facing the nation. Corporate growth is sometimes seen as widening the gap between India and Bharat through its income-skewing capability. This gap needs to be bridged. While the Government undertakes extensive developmental 
initiatives through a series of sectoral programmes, the business sector also needs to take the responsibility of exhibiting socially responsible business practices that ensures the distribution of wealth and well-being of the communities in which the business operates.

Salman Khurshid, Minister of State for Corporate Affairs [1]

\section{Introduction}

Most nations have directed their policies towards making business the engine of socioeconomic development and, in response, the private sector has generated heretofore unimaginable growth rates, wealth, and profits. By placing business at the center of national interests, corporate headquarters now define the skylines of major cities and, in developed economies, have replaced religion as the new sites of worship [2]. Despite enabling policies and infrastructural support for the burgeoning private sector, many national and regional governments are paralyzed by their debt burdens, lack of revenue streams, mounting civic responsibilities, and growing public discontent and distrust [3]. While the needs of society were traditionally part of the remit of the state, corporate power challenges and undermines this custodianship [2-7]. Shifting responsibilities between the state, its citizens, and the private sector raise important questions about who is responsible for what and for whom?

Whether motivated by benevolence, shared value creation, enlightened self-interest, capturing market share, image building, or a combination of these, the long-term success and sustainability of firms is closely associated with the wellbeing and prosperity of the societies within which they are embedded, as the long-term success and sustainability of societies is associated with the success of their economic activities. Over time and with the rise and mobility of corporate power, the reciprocity and interdependence between business and society have weakened. Attributing clear responsibilities between increasingly impoverished and weakened governments, and increasingly wealthy, mobile, and autonomous businesses has become a major challenge [3].

The aim of political CSR is to study the evolving interdependencies between politics, business, and society. Broadly speaking, the field may be divided into bottom-up political mechanisms legitimizing corporate behavior and regulatory top-down approaches. Most of the literature on political CSR focuses on bottom-up mechanisms relating to the expansive and expanding role of business as firms assume societal responsibilities previously associated with the state [8]. Examples include initiatives to reduce poverty, develop and manage infrastructure, or provide access to health, education, and other services [9-11]. This variant is premised on three characteristics. First, the bottom-up adoption of proactive responsibilities is viewed as intrinsically voluntary [12-14]. In this regard, taking on societal or governmental responsibilities is perceived as a strategy to garner political favor or to avoid regulation [13,15-17]. Second, it is assumed that governments confined by fiscal limitations are increasingly unable to meet their responsibilities without the assistance of the business sector [8,18-20]. Firms fill this vacuum in contexts where national governance structures are weak, unstable, or absent [21-24]. Finally and as a consequence, exercising political CSR is strategically beneficial to firms [12-14] because responding to social demands in contexts where they have become the most powerful actors with significant political influence ensures access to markets and a benevolent regulation environment $[2,25]$.

Recent evidence suggests that governments are increasingly and explicitly adopting top-down mechanisms of political CSR as a policy tool to address societal needs or environmental management $[8,26,27]$. These approaches signal a reformulation of political expectations for business to engage beyond the economic domain and increase their commitment to social and environmental issues. Notable examples include CSR regulations introduced in China in 2006 [28], the corporate and investment laws regulating social and environmental responsibilities in Indonesia since 2007 [29], the $2 \%$ CSR mandate introduced in Mauritius in 2009 [30], Denmark's National Action Plans for CSR in 2008 and 2012 [31], and India's Companies Act 2013 [32,33]. The Business Roundtable's Statement of Purpose of a Corporations from August 2019, signed by 181 US CEOs under the chairmanship of Jamie Dimon, is in line with this global trend. While the debate concerning mandatory versus voluntary 
responsibilities is still the defining characteristic of political CSR, the general consensus seems to be that CSR could be used to complement rather than challenge or replace corporate governance $[34,35]$. In most cases, it is viewed as a way to standardize CSR involvement across sectors, promote sustainable corporate practices, and foster transparency and accountability [25,30]. Especially in emerging markets where governments often lack the regulatory frameworks and enforcement capacities to guide corporate behavior, top-down approaches represent an opportunity to direct corporate awareness to social and environmental challenges [24]. Significantly, it also represents a way for governments to connect the sustainability agenda - often set by external actors, such as buyers, investors, shareholders, or international standard-setting organizations [24]—with local culture, context, needs, and expectations.

Systematic studies examining the consequences of corporate responsibility as a policy tool in emerging economies are absent, limiting our understanding of this evolving component of the business-society nexus. The aim of this study is to contribute to this emerging field by examining political CSR in India, specifically how the Companies Act 2013 is evaluated by academia.

\section{Background}

Despite geopolitical shifts that have caused far-reaching global uncertainties over the past decade, India's economy has remained robust, with steady GDP growth at above 6\% [36]. Thus far, the forecast by the International Monetary Fund —-that India's growth would become the highest worldwide-is on track [37]. The collective revenue of the top ten Indian Fortune 500 enterprises have increased steadily from just over Rs. 21 trillion in 2016 [38] to more than Rs. 23 trillion in 2017 [39], and Rs. 27 trillion in 2018 [40]. India's Foreign Direct Investment exceeded USD 10 billion in December 2018, up from USD 7.0 million in June 1991 [41]. Economic expansion has translated into upward socioeconomic mobility for its citizens, especially the upper-middle and rapidly expanding middle classes. Access to basic infrastructure and services, however, remain a significant challenge [42,43]. The latest census data indicated that $74 \%$ of the rural population earned less than Rs. 5000 (approximately USD 72) per month, and $24 \%$ of the urban population still lived in slums in 2014 [44].

Such disparities have traditionally been addressed, at least in part, by India's long-standing commitment to corporate philanthropy [45-47]. While enjoying some success, philanthropic activities fall well short in addressing even extreme forms of poverty, let alone providing basic services for the majority of the population. Given India's sizeable population and associated challenges in light of its growing geopolitical influence and socioeconomic development potential, a popular government could realign India's developmental trajectory toward greater sustainably [48]. It is within this context that Prime Minister Narendra Modi developed his political platform, utilizing economic growth to activate social development. The resulting Companies Act 2013 [49] led the Indian government into unchartered territory as it explicitly and legislatively redefined the relations between business and society. His recent reelection illustrates the broad support of this strategy.

Based on these policies, what is the business-society nexus in India, and how is it shaped by its context and culture? Since 2009, the Indian government has taken progressive steps to formalize responsibilities of firms toward the Indian society and its citizens, first with the National Voluntary Guidelines on Social, Environmental and Economic Responsibilities of Business [1] and, through successive steps, by introducing the Companies Act 2013 and subsequent variants. Section 135 of the Act outlines what the government defines as CSR expectations. For example, it stipulates that all firms with a "net worth of rupees five hundred crore or more, or turnover of rupees one thousand crore or more or a net profit of rupees five crore or more during any financial year" must establish an independent board level CSR committee [49] (p. 87). The committee must ensure that "the company spends, in every financial year, at least two per cent of the average net profits of the company made during the three immediately preceding financial years, in pursuance of its Corporate Social Responsibility Policy" [49] (p. 87). The committee is expected to formulate and recommend CSR policy, as well as oversee the implementation thereof. According to Schedule VII of the Act (see Table 1), the committee also must ensure that CSR activities "give preference to the local area and areas 
around it where it operates" [49] (p. 87). Initially, the Act stipulated that, if the company fails to spend the $2 \%$ of its profits, it is to publicly report "the reasons for not spending the amount" [49] (p. 87). On 26 July 2019, the Lok Sabha, the House of the People (lower house of the bicameral Parliament of India), passed the Companies Act (Amendment) Bill 2019 [50], which stipulates that firms which fail to spend the required amount will face fines and their officers potential imprisonment. All unspent money would be transferred to a special account, to be spent on CSR activities. The list of activities in which firms are expected to invest are listed in Table 1.

Table 1. Schedule VII, List of corporate social responsibility activities proposed by government (amended 30 May 2019) [49].

\begin{tabular}{|c|c|}
\hline \multicolumn{2}{|r|}{ Schedule VII, List of CSR Activities } \\
\hline (i) & $\begin{array}{l}\text { Eradicating hunger, poverty and malnutrition, promoting health care including preventive health care } \\
\text { and sanitation including contribution to Swach Bharat Kosh set-up by the Central Government for } \\
\text { promotion of sanitation and making available safe drinking water; }\end{array}$ \\
\hline (ii) & $\begin{array}{l}\text { Promoting education, including special education and employment enhancing vocation skills especially } \\
\text { among children, women, elderly, and the differently-abled and livelihood enhancement projects; }\end{array}$ \\
\hline (iii) & $\begin{array}{l}\text { Promoting gender equality, empowering women, setting up homes and hostels for women and orphans; } \\
\text { setting up old age homes, daycare centres and such other facilities for senior citizens and measures for } \\
\text { reducing inequalities faced by socially and economically backward groups; }\end{array}$ \\
\hline (iv) & $\begin{array}{l}\text { Ensuring environmental sustainability, ecological balance, protection of flora and fauna, animal welfare, } \\
\text { agroforestry, conservation of natural resources and maintaining quality of soil, air and water including } \\
\text { contribution to the Clean Ganga Fund set-up by the Central Government for rejuvenation of the river } \\
\text { Ganga; }\end{array}$ \\
\hline$(\mathrm{v})$ & $\begin{array}{l}\text { Protection of national heritage, art and culture including restoration of buildings and sites of historical } \\
\text { importance and works of art; setting up public libraries; promotion and development of traditional arts } \\
\text { and handicrafts; }\end{array}$ \\
\hline (vi) & Measures for the benefit of armed forces veterans, war widows and their dependents; \\
\hline (vii) & Training to promote rural sports, nationally recognised sports, Paraolympic sports and Olympic sports; \\
\hline (viii) & $\begin{array}{l}\text { Contribution to the Prime Minister's National Relief Fund or any other fund set up by the Central } \\
\text { Government for socio-economic development and relief and welfare of the Scheduled Castes, the } \\
\text { Scheduled Tribes, other backward classes, minorities and women; }\end{array}$ \\
\hline (ix) & $\begin{array}{l}\text { Contributions or funds provided to technology incubators located within academic institutions which are } \\
\text { approved by the Central Government; }\end{array}$ \\
\hline$(\mathrm{x})$ & Rural development projects; \\
\hline (xi) & Slum area development; \\
\hline (xii) & Disaster management, including relief, rehabilitation and reconstruction activities. \\
\hline
\end{tabular}

Mandating what has been considered voluntary in the past introduced a novel and momentous definition of the role of business in society. To better understand this metamorphosis of CSR into a context- and culture-specific interpretation by the Indian state, we examine how academia, especially economics, business and management studies, and related sciences, responded to the Act. More specifically, we analyzed the academic perspectives on the Companies Act 2013 to develop a typology of its reported strengths and weaknesses, and the recommendations made to further develop the Act in the service of a business-society nexus. Based on this focus, two research questions guided this analysis: What are the advantages and disadvantages of the Company's Act 2013 as debated in academia?, and What strategies and recommendations are proposed to improve the implementation of CSR in India?

\section{Materials and Methods}

Data for this qualitative study are comprised of academic papers on the Companies Act 2013. Four sampling criteria were used to select academic texts: type of publication, focus, timeframe, 
and language. We identified relevant literature using online search engines, library catalogues, and journal websites from a wide range of disciplines, including business and management studies, economics, finance, commerce, accounting, law, business ethics, sociology, social work, as well as sustainability studies. All sampled texts explicitly focused on the Companies Act 2013 and were published between January 2013 and August 2019. Based on these criteria, the final sample consisted of 70 regional, national, and international English-language book chapters, research articles, reports, reviews, and published expert commentaries [45-47,51-117].

To develop a typology of the advantages and disadvantages associated with the Companies Act 2013, we employed Content Configuration Analysis [118,119], a qualitative method for the systematic analysis of non-numeric data related to thematic and content analysis. This method has been employed in the fields of business and management studies, business ethics, economics, education, psychology, sociology, sustainability studies, and mobility studies [26,28,118-120].

We used a two-step analysis to develop our typology. First, we randomly selected a sub-set of articles ( $n=20$ articles) to conduct an in-depth, exploratory analysis. For this, we identified all implicit and explicit statements relating to the advantages and disadvantages of the Act. We sorted and classified the statements to derive an initial typology, which we then used as an analytic framework for a quasi-deductive analysis, sorting and classifying the remaining texts to adapt and refine the typology. Table 2 represents the final taxonomy of the advantages and disadvantages of the Act based on our data. In the last step, we identified, sorted, and classified the authors' recommendations on how to improve the Companies Act 2013.

\section{Results}

One of the most distinguishing features of the Companies Act 2013 is the clear demarcation of the content and its boundaries of a policy-driven interpretation of CSR, which reveals strong associations with India's social, economic, and political context and culture. Based on our analysis, advantages and disadvantages are divided into two domains: conceptual and theoretical issues associated with advantages and disadvantages, and the positive and negative impacts of the Companies Act 2013 on stakeholders.

Conceptual issues concern the theoretical boundaries of CSR as defined in the Act, which include whether CSR should be anchored to a legal spending minimum, whether CSR is philanthropic, and whether CSR should be mandated. Advantages and disadvantages related to stakeholder perspectives concern how firms, government, Indian society, communities, and especially the poor are affected by the Act (Table 2).

Table 2. Academia's perspective on the advantages and disadvantages of the Companies Act 2013.

\begin{tabular}{lcl}
\hline \multicolumn{1}{c}{ Advantages } & \multicolumn{1}{c}{ Disadvantages } \\
\hline & Conceptual dimensions of CSR & \\
Legal minimum & vs & Anchoring effect \\
CSR is philanthropy & vs & CSR is not philanthropy \\
Institutionalization of CSR & vs & Mandating CSR \\
\hline & CSR Stakeholders & \\
CSR know-how & Firms & Lack of skills \\
Aligning CSR is good for business & vs & CSR is antagonist to business practice \\
Transparency and accountability & vs & Greenwashing \\
& vs & \\
Institutionalizing CSR & Government & Lack of monitoring CSR \\
Shared responsibility & vs & Shifting responsibility \\
& vs & \\
Increased equality & Society & Increased inequality \\
Increased partnership & vs & Lack of collaboration \\
\hline
\end{tabular}




\subsection{Advantages and Disadvantages Associated with the Conceptual Dimensions of the Companies Act 2013}

\subsubsection{Legal CSR Minimum vs CSR as Insufficiently Anchored}

According to academia, the $2 \%$ spending minimum has multiple advantages and disadvantages. On the one hand, it is argued that the Act successfully engineers a set legal minimum for CSR investment, which is expected to significantly increase the overall financial commitment to Indian society and, thus, reinforce commitments to societal wellbeing [56,58,66,75,114,115]. Interestingly, this argument is also presented as a disadvantage. According to authors embracing this position, past contributions by many firms were substantially higher than $2 \%$, thus, inadvertently lowering CSR investments. In line with this argument, a philanthropic or benevolent commitment to society is reduced to a CSR tax [63-66,68,90,97]. Accordingly, an unintended consequence may be a shift from quality to quantity, or from long-term societal commitments to short-term projects and programs $[63,64,68,90,97]$. Here are two examples from the literature:

We infer that this limit was imposed with a view to stimulate corporate spending on social causes and maybe to make the growth experienced by corporations more inclusive of the society as a whole. This minimum spending limit does have the potential of increasing the number of companies investing in CSR activities. [66] (p.9)

While there were few firms that spent more than $2 \%$ prior to Section 135, these firms appear to have decreased their CSR spending after Section 135 came into effect; presumably, this was an unintended and undesired outcome. (...) the threshold becoming both a ceiling and a floor (or an "anchor"). [68] (p. 103)

\subsubsection{CSR and Philanthropy}

The differentiation to philanthropy as conceptualized in the Act reveals another layer of tension between its advantages and disadvantages. According to some authors, traditional philanthropic activities are preserved since firms can continue to invest in health- or education-related initiatives, or donate their 2\% contribution to the Prime Minister's National Relief Fund [63,64,73,87,102,105]. Explicitly excluded in the Act, however, are donations or gift-giving to charities, leading others to claim that the true philanthropic nature of CSR has been fundamentally undermined $[64,65,73,90]$. Here, two examples of these contrasting positions:

The potential for corporate philanthropy to lessen poverty has been recognized by the Companies Act 2013, which, in Schedule VII, specifies 'eradicating extreme hunger and poverty' as an allowable CSR activity (Government of India 2013, p. 294). [73] (pp. 687-688)

The act clearly demarcates CSR from charity and does not position it as a 'moral responsibility' for companies. Charities and donations are outside the purview of CSR. [90] (p. 23)

\subsubsection{Mandating CSR}

Advantages associated with mandating CSR are rare. When present, they link the institutionalization of CSR with public concerns over rising corporate irresponsibility $[61,69,86,94,114]$. Far more prevalent are debates on the disadvantages and challenges associated with mandating something, which traditionally was considered discretionary. While some argue that CSR in India is contradicting international or Western normative or business practices [51,59,92,110,111,117], others argue that CSR in the form of philanthropy is a natural and discretionary part of business and should remain voluntary, lest the "unique joy and benefits that flows from giving back to society" be removed [79] (p.7) (see also [64,83,103,110]). According to this view, mandating CSR may jeopardize firms' willingness to engage with society, resulting in passive participation $[45,57,59,64,65,90,101]$. Here two examples: 
The boom in the economy during the last decade and rising global concerns about corporate social irresponsibility triggered the debate about public policy on CSR. ( ... ) The Companies Act, 2013 provided the much needed articulation to the concerns of public. [86] (pp. 156, 157)

These and other related arguments for CSR stems from the fact that, contributing to the social welfare of people is a charitable act. Making CSR mandatory defeats the natural laws of donation thereby shifting CSR as a charitable act to new realm of increasing the tax burden of companies. [79] (p. 2)

As the above illustrates, there are several debates in the literature on the benefits and challenges associated with the Act. The varying positions in our data illustrate how its dimensions intertwine with CSR investment, legal obligations, and philanthropy, blurring the line between what ought to be voluntary or mandatory. Within this conflict, CSR as defined in the Act is presented as a needed measure, inadequate, an unnecessary tax, or as outright detrimental for business competitiveness, but also as a measure that strengthens the philanthropic spirit of CSR and an effective legislature that assists in alleviating extreme forms of poverty and addresses social problems.

\subsection{Advantages and Disadvantages from a Stakeholder Perspective: Firms, Government, and Society}

\subsubsection{Advantages and Disadvantages Associated with Firms}

The second domain of advantages and disadvantages connects to stakeholder groups, namely firms, (local and national) government, and society (including communities, regions, and "the poor"). Table 3 lists the advantages and disadvantages associated with firms. Advantages include how provisions in the Act capitalize on corporate know-how, how aligning CSR in this way is good for business in the long run, and how the implementation of the Act will increase transparency, accountability, and corporate citizenship.

Table 3. Advantages and disadvantages associated with firms.

\begin{tabular}{lcl}
\hline \multicolumn{1}{c}{ Advantages } & & \multicolumn{1}{c}{ Disadvantages } \\
\hline The Act capitalizes on corporate know-how & vs & $\begin{array}{l}\text { Lack of corporate know-how and skills to engage } \\
\text { outside of their area of expertise } \\
\text { Aligning CSR based on the Act is bad for business }\end{array}$ \\
$\begin{array}{l}\text { Aligning CSR is good for business } \\
\begin{array}{l}\text { The Act increases corporate transparency } \\
\text { and accountability }\end{array}\end{array}$ & vs & $\begin{array}{l}\text { vs } \\
\text { Evading CSR mandate may increase greenwashing } \\
\text { and under- or misreporting }\end{array}$ \\
\hline
\end{tabular}

The Companies Act 2013 requires firms to create a CSR committee with a strategic agenda, dedicated staff, and reporting and monitoring mechanisms. According to the literature, there are multiple advantages associated with embedding CSR in a firm in this way. First, integrating CSR into the core operations of business will capitalize on corporate know-how and enable initiatives to leverage existing management and strategic capacities $[53,54,59,68,78,89,110,111,113]$. Second, the Act compels firms to embed economic, social, and environmental objectives into their core business strategy, projects, and processes $[45,69,70,86,87,105,107]$, which results in improved stakeholder relations and new business opportunities $[58,67,68,90,92,97,105]$, competitive advantage $[75,104,105]$, or enhanced efficiency relating to CSR activities $[45,69,78,107]$. By enforcing the disclosure of CSR practices, the Act furthermore promotes transparency and accountability $[47,61,63,64,69,76,88,89,97,105,109,117]$, and it assists in unifying sporadic CSR activities by standardizing procedures [59,77,90,97]. Here, three examples from the literature:

Corporations have the know-how, strategic thinking, manpower, and financial strength to enable widespread social transformation. [110] (p. 459)

Integrating social environment and ethical responsibilities into the governance of business ensures their long-term success, competitiveness and sustainability. [105] (p. 34) 
Today, CSR in India has gone beyond merely charity and donations, and is approached in a more organized fashion. It has become an integral part of the corporate strategy. Companies have CSR teams that devise specific policies, strategies and goals for their CSR programs and set aside budgets to support them. [54] (p. 78)

Contradicting these advantages, others point out that firms lack the necessary know-how to effectively pursue the large-scale CSR programs proposed in the Act because it stipulates that CSR initiatives cannot fall within the area of expertise or business interests of firms. Forcing businesses to engage in areas where they have no experience or interest may sidestep valuable skill sets and sector-specific know-how, and it may lead to inefficient and uncommitted CSR projects and programs $[45,47,59$, $62,65,67,70,72,78,80,81,88,90,100,101,105,108,112,116]$. Another disadvantage relates to the idea that the CSR formulation in the Act has a negative impact on business. The main premise here is that all activities undertaken "in pursuance of the normal course of business" cannot be considered as CSR [65] (p. 90) (see also [53,63,100]). This includes initiatives aimed at improving operational efficiency [64], developing and supporting employees [63,64,90,100], and activities that may generate profits, including all forms of shared value creation $[51,57,64,65,79,87,88,90,91]$. The Act's focus on mainly large and successful national firms inadvertently provides a competitive advantage to small, unprofitable, or international firms, which are currently exempt from participating in the CSR activities as outlined by the Act $[45,55,72,74,78,83,107]$. Finally, some argue that, instead of increasing transparency and accountability, attempts to evade the mandate may actually increase the prevalence of greenwashing as firms either underreport their profits or misreport their involvement in CSR activities $[51,55,58,66,74,78,82,84,107,110]$. Here are some examples:

In a nutshell, many companies, especially those with little or no previous experience with CSR, will likely face challenges right from planning through to implementation, monitoring, measurement and reporting. [100] (p. 100)

In the case of Jain Irrigation, while farmers' income received a boost, so did profitability of the company. Of course, in the context of the Companies Act 2013, it will be a challenge to convince the government that such initiatives were not part of the normal course of business and that it could qualify for CSR activities as per the Act. [63] (p. 10)

$\ldots$ only activities that are not exclusively for the benefit of employees of the company or their family members will be considered as CSR activities. In other words, if a company provides elementary education for children of its plantation workers, such expenditure would not be eligible CSR spend[ing]. [90] (p. 24)

However, industry is apprehensive that implementations of this provision is bound to throw up challenges because of the rather prescriptive manner in which rules have been formulated. There is a concern on flexibility within legitimate boundaries and how the monitoring and interpretation of companies' efforts will take place. Further, the industry grouping said the rules do not provide clarity on certain issues. [59] (p. 1)

\subsubsection{Advantages and Disadvantages Associated with Government}

There are two types of advantage associated with government (Table 4). The first concerns taking control of CSR projects and programs by formalizing and institutionalizing CSR activities in India $[61,69,86,94,115]$. The second refers to benefits associated with sharing and managing societal responsibilities between government and business $[45,51,54,70,71,85,95,96,110]$. In contrast, others argue that the government did not sufficiently take control of the CSR landscape because it is not sufficiently monitoring its implementation. Instead, CSR projects and programs are left to what is considered an inadequate 'report or explain' clause [64,74,79,84,99,107]. Accordingly, the lack of adequate oversight allows corrupt government officials to use the Act to further their personal agendas. 
Specifically mentioned are national projects and the Prime Minsters Relief Fund, which, according to these authors, lack transparency and enjoy a privileged tax status $[59,97,100,110]$. Finally, those who oppose sharing societal responsibility argue that the care and wellbeing of society ought to be the responsibility of the government. Mandating and restructuring CSR in accordance with the Act is an abdication of its fundamental duties $[64,78,79,90,91,107,110]$. In line with this argument, the Act is viewed as a $2 \%$ business tax increase, with the additional burden of being tasked to taking care of society's central needs $[59,63,64,71,72,75,78,79,83,90,103,107,108,110,111]$. Here some examples:

Table 4. Advantages and disadvantages associated with government.

\begin{tabular}{|c|c|c|}
\hline Advantages & & Disadvantages \\
\hline $\begin{array}{l}\text { The government is taking control of the } \\
\text { CSR landscape }\end{array}$ & vs & $\begin{array}{l}\text { The government is not monitoring CSR activities } \\
\text { sufficiently, 'report and explain clause' }\end{array}$ \\
\hline $\begin{array}{l}\text { The Act shares societal responsibility } \\
\text { between the government and firms }\end{array}$ & vs & $\begin{array}{l}\text { The government is abdicating its responsibility of } \\
\text { taking care of society }\end{array}$ \\
\hline
\end{tabular}

A related (political) issue is that the Act allows companies to use their CSR funds to support development projects initiated by the Prime Minister or Central Government. Additionally, the 2015 federal budget allows $100 \%$ tax exemption for contributions to selected national projects and contributions to Prime Minister's National Relief Fund. Although some of these national projects can have significant environmental impacts if implemented properly, the proposed tax exemptions could become vehicles for political patronage, and be used as indirect political payoffs. It is worth noting here that India Inc. has been demanding that CSR spending be allowed as deduction or weighted deduction for the purpose of computing tax liability, a request that has not been conceded yet. [100] (p. 96)

The CSR Bill refers to a new form of welfare governance in India that moves part of the burden of social policy expenditure away from the state to the private sector. ( ... ) It is an opportunity for the corporate sector to contribute to social development and preserve the legitimacy of state support to economic value creation and growth. [80] (p. 832)

Lack of proper monitoring mechanism for the mandatory CSR regulation is a pertinent challenge. [99] (p. 300)

The role of the government is to promote and improve the welfare of the society by providing educational facilities, transport and communication, hospital, improve the standard of living of people. Companies on the other hand aimed to maximise the profit of the firm and not to improve the welfare of the society. But making corporate social responsibility mandatory is to shift the role of government to corporate. [79] (p. 7)

\subsubsection{Advantages and Disadvantages Associated with Society}

Advantages of the Companies Act 2013 are mainly associated with large-scale societal upliftment (Table 5). According to the literature, CSR investment induces inclusive economic growth, promotes greater societal equality, and enhances sustainable development $[46,54,59,61,63,66,75,77,78,80,81,87$, $90,91,97,107,110,113]$. Other advantages to society relate to new and enhanced partnerships between stakeholders: As different stakeholders enter into partnerships and collaboratively develop, implement, and monitor CSR projects and programs, the collaboration increases local knowledge and acceptance, improves effectiveness, and secures the long-term sustainability of CSR initiatives $[45,47,55,57,61,63-$ $65,67,70,80,81,86-98,102,108,111,112]$. 
Table 5. Advantages and disadvantages associated with society.

\begin{tabular}{lll}
\hline \multicolumn{1}{c}{ Advantages } & \multicolumn{1}{c}{ Disadvantages } \\
\hline $\begin{array}{l}\text { More inclusive growth, greater equality, } \\
\text { and more sustainable development }\end{array}$ & vs $\quad \begin{array}{l}\text { The geographic and thematic limitation imposed } \\
\text { by the Act will increase inequality and disparity } \\
\text { among states } \\
\begin{array}{l}\text { Increased partnerships and collaboration to } \\
\text { implement CSR }\end{array}\end{array}$ vs $\quad \begin{array}{l}\text { Meaningful collaboration and partnerships are } \\
\text { missing }\end{array}$ \\
\hline
\end{tabular}

The counterargument states that the geographic and thematic limitations imposed by the Act exacerbate inequality between regions and may exacerbate regional, religious, and ethnic tensions. Authors who embrace this position highlight a clause in the Act, which stipulates that firms should invest in the communities where they operate. Accordingly, this disadvantages communities that are located in regions with little industry, especially regions with little industry and many rural areas $[59,65,97,100,103]$. In terms of thematic limitations, authors also point out that the CSR activities stipulated in the Act channel corporate investment into certain thematic areas while neglecting others $[59,65,66,97]$. Furthermore, some academics argue that the envisioned collaboration cannot be achieved through the mechanisms engendered by the Act. Some challenges include the lack of consultation with local partners and top-down approach of projects or programs, which fail to consider local needs, contexts, and cultures $[45,47,73,74,81,97,105]$. This is exacerbated by a dearth of well-organized and experienced NGOs or NPOs to develop, implement, monitor, and report on CSR activities [45-47,55,62,73,74,81,100,105], as well as resistance by local communities to intervention programs due to a lack of knowledge about the aims thereof or suspicion of ulterior motives of regional or national government, businesses, or NGOs and NPOs associated with a specific intervention $[45,47,55,62,74,81,86,95,96,98,102,104,105,115]$. In line with this, local suspicions are often understandable, given that many interventions contradict, rather than coordinate with or integrate, local customs, hierarchies, and traditions. Here are some excerpts:

Recognising the need for inclusion of socially underprivileged sections of the society in India's growth story, the new company law of 2013 has come up with a mandate for giant corporates to shell out at least two percent of their three years' annual average profits toward Corporate Social Responsibility (CSR) activities. [107] (p. 757)

It is difficult for one single entity to bring about change, as the scale is enormous. Effective partnerships between corporate, NGOs and the government will place India's social development on a faster track. [45] (p. 12)

Schedule VII of the rules specifically mention a list of activities which may be included by companies in their CSR policies, along with a customary line "such other matters as may be prescribed". The recommended activities are already being circulated by many agencies and individuals and are being accepted by many corporate as the preferred activities for CSR. This is not only polarizing the CSR resources to few chosen are-as, but also discouraging many other critical areas. [59] (p. 3)

Often, the communities who are the intended beneficiaries of a CSR program show less interest which will affect their participation and contribution. Also, very little efforts are being made to spread CSR within the local communities and instill confidence in the people. The situation is further aggravated by inadequate communication between the organization and the community at the grassroots level. [74] (p. 24)

Also here, the advantages and disadvantages of the Act are presented in conflicting, contradictory, or oppositional terms. For firms, this means that managerial and strategic know-how either enhances CSR projects and programs, or that firms lack the know-how and motivation to engage in activities that 
fall outside of their areas of interest and expertise. Another area of contention concerns accountability: CSR as proposed by the Act ostensibly leads to either more or less transparency, accountability, corporate citizenship, misreporting of revenue, misrepresenting CSR engagement, or greenwashing. Especially interesting are the contrasts associated with society, the one stakeholder that ought to benefit most from the Act. Here, academics point out that specifying where and on what CSR investments should focus either reduces or exacerbate geographical and social disparities and conflicts, and the goal of creating strong partnerships either is promoted or has not materialized. Interesting also is that the disadvantages associated with the Act for government, businesses, and society (the latter includes regions, social groups, and "the poor") as reported in our data outnumber the advantages by four to one.

\subsection{Recommendations to Address CSR Challenges}

Based on the reported advantages and disadvantages of the Act, we sorted and classified recommendations made by academics on how to overcome obstacles or further improve on its advantages. Recommendations are divided into two domains: theoretical and conceptual issues, and issues relating to stakeholders.

\subsubsection{Conceptual Dimensions}

Despite the many objections to mandate what ought to be discretionary, many authors nevertheless considered the current CSR activities as vital for the socioeconomic development of Indian society. Only one author offered an alternative to mandating CSR by calling on the government to replace the legalistic with a philosophic approach akin to a trusteeship as proposed by Mahatma Gandhi, Milton Friedman, and Adam Smith [64]. While this would preserve the voluntary nature of CSR, no concrete recommendations are provided as to what this may mean or how this should be institutionalized. Table 6 includes all other recommendations in support of mandating CSR and provide further suggestions on how to refine its focus. Recommendations include how to penalize firms if they fail to contribute adequately $[56,57,65,84,85,99]$, under what condition firms should be relieved of their spending duties $[65,82]$, which concessions could be made for firms that invest in additional or alternative CSR schemes [99], and how to credit or integrate CSR spending into tax schemes [47,53,82, $101,110,111,116,117]$.

Table 6. Recommendations associated with the conceptual dimensions of the Act.

\begin{tabular}{|c|}
\hline Conceptual Recommendations \\
\hline Advantage: Mandating CSR as a form of institutionalization \\
\hline $\begin{array}{l}\Rightarrow \quad \text { Firms who fail to spend their } 2 \% \text { should be penalized, or unspent money should automatically be } \\
\text { deposited into long-term, multi-year government programs }\end{array}$ \\
\hline $\begin{array}{l}\Rightarrow \quad \text { Exceptions or concessions should be made for (a) financially distressed firms, (b) those who participate in } \\
\text { other CSR schemes, and (c) all CSR contributions should be made tax-deductible }\end{array}$ \\
\hline Disadvantage: Mandating that which should be voluntary \\
\hline$\Rightarrow \quad$ Replace legalistic with a philosophical approach to CSR \\
\hline
\end{tabular}

\subsubsection{Firms}

The CSR recommendations concerning firms (Table 7) follow a two-pronged approach. Firms ought to overcome their bias against CSR initiatives. For now, projects are considered too limited in scope and ambition with a focus on a project-by-project basis, or too narrowly focused on sector-specific skills and expertise. They recommend that CSR programs should be incorporated into corporate visions and strategies in order to develop ambitious, effective, and holistic CSR programs that could bring about long-term socioeconomic change in regions and communities $[47,59,69,70,81,99,102,109]$. According to the literature, the most efficient way to achieve this would be to establish professional teams to develop, implement, monitor, and maximize CSR capacities on behalf of firms by collectively 
managing CSR funds $[47,59,81,87,102,107]$. Finally, and in contrast to the first recommendation, it is argued that CSR activities should be nested within existing skill sets, interests, and expertise of firms in order to drive entrepreneurship, innovation, and long-term growth for the shared benefit of firms and society through CSR initiatives [53].

Table 7. Recommendations by academia to overcome disadvantages associated with firms.

\begin{tabular}{l} 
Disadvantages for Firms and Recommendations \\
\hline $\begin{array}{l}\text { Disadvantage: Lack of corporate know-how and skills to engage outside of their area of expertise } \\
\Rightarrow \quad \text { Firms should overcome sector- and skill-specific biases in CSR engagement to develop holistic programs } \\
\text { to bring about long-term, socioeconomic change }\end{array}$ \\
$\Rightarrow \quad$ Firms should establish professional teams to define, implement, monitor, and manage CSR funds \\
and projects \\
$\begin{array}{l}\text { Disadvantage: Aligning CSR with the thematic scope of the Act is bad for business } \\
\Rightarrow \quad \text { To enable win-win CSR investments, activities should be situated within their areas of expertise }\end{array}$
\end{tabular}

\subsubsection{Government}

According to our data, government ought to monitor more stringently the implementation of the Act (Table 8). Recommendations include providing statutory guidelines to better define CSR initiatives [102], or establishing performance monitoring indices and standards, to be overseen by an independent authority $[47,58,74,110,115]$. To make CSR investments more transparent and firms more accountable, some authors suggest integrating CSR activities and expenditures in the annual financial statements or making annual CSR reporting mandatory $[58,74,102,106,110]$. Finally, some authors argue for restricting CSR funding toward government-run schemes to limit the potential for misappropriation $[59,100]$.

Table 8. Recommendations by academia to overcome disadvantages associated with government.

\begin{tabular}{|c|c|}
\hline \multicolumn{2}{|r|}{ Governmental Disadvantages and Recommendations } \\
\hline \multicolumn{2}{|r|}{ Disadvantage: The government is not monitoring CSR sufficiently, 'report and explain clause' } \\
\hline$\Rightarrow$ & $\begin{array}{l}\text { The government should adopt a more elaborate CSR monitoring mechanism to ensure investments } \\
\text { are made }\end{array}$ \\
\hline$\Rightarrow$ & $\begin{array}{l}\text { The government should (a) provide statutory guidelines to direct CSR efforts, (b) assist in the } \\
\text { establishment of independent performance monitoring standards, and (c) make annual } \\
\text { reporting mandatory }\end{array}$ \\
\hline$\Rightarrow$ & $\begin{array}{l}\text { Limit the potential of corruption by placing limits on the PM's Fund and making government programs } \\
\text { more transparent }\end{array}$ \\
\hline
\end{tabular}

\subsubsection{Society}

Recommendations to improve the societal impact of the Act (Table 9) refer to issues of inequality and societal stakeholder engagement. According to the literature on the Act, the geographic reach of CSR initiatives ought to be expanded beyond the communities in which firms operate, specifically to integrate rural development [47-59]. Furthermore, the list of activities that qualify as CSR-relevant in Schedule VII ought to be expanded to include additional priority areas $[59,101,109]$. A four-pronged approach is suggested to increase meaningful collaboration between stakeholders. First, firms should increase their CSR capacities by identifying and capitalizing on local knowledge and technical expertise to make initiatives more scalable and results-oriented [47,74]. Second, firms should collaborate with one another and with local development organizations, NGOs, and NPOs to create synergies and to build region- and project-specific know-how $[47,59,74,81,87,98,105,107,116]$. Third, firms should develop awareness campaigns to increase public awareness of the scope and potential of CSR initiatives, as well as to increase public support and cooperation $[45,47,54,70,115]$. Finally, business and government 
ought to invest in expanding CSR education and training to create a pool of local specialists with the capacities to create and oversee collaborative initiatives [91].

Table 9. Recommendations by academia to overcome disadvantages associated with society.

\begin{tabular}{|c|c|}
\hline \multicolumn{2}{|r|}{ Societal Disadvantages and Recommendations } \\
\hline & dvantage: The geographic and thematic limitation imposed by the Act will increase inequality \\
\hline$\Rightarrow$ & Expand the geographic reach of the Act and the list of activities in Schedule VII \\
\hline$\Rightarrow$ & Disadvantage: Meaningful collaboration and partnerships are missing \\
\hline$\Rightarrow$ & $\begin{array}{l}\text { Firms should develop more effective strategies to identify and capitalize on local knowledge and } \\
\text { technical expertise to increase the potential for meaningful collaboration }\end{array}$ \\
\hline$\Rightarrow$ & $\begin{array}{l}\text { Firms should develop and implement public awareness campaigns to increase public knowledge of and } \\
\text { support for CSR initiatives }\end{array}$ \\
\hline & $\begin{array}{l}\text { Business and the government should invest in training programs to develop a pool of qualified } \\
\text { specialists to oversee CSR initiatives }\end{array}$ \\
\hline
\end{tabular}

Despite the large number and range of criticisms associated with the Companies Act 2013, the literature contains relatively few recommendations on how to address them. Most recommendations do not suggest major adjustments but focus instead on strategies to enhance the effectiveness of the Act. Most authors propose that firms should enlist the help of independent professional teams to develop, implement, monitor, and maximize CSR capacities. This would ostensibly overcome the lack of firms' engagement and expertise in the intervention area. External bodies would also measure, monitor, and report on the impact of CSR initiatives more objectively and systematically, and they would foster collective networking, capacity building, and multi-stakeholder partnerships. From a government perspective, independent agencies would take on the role of an accountability watchdog, monitoring CSR performance of firms, establishing performance monitoring standards and indices, and facilitating compliance and evaluation. From a societal perspective, suggestions to better secure the long-term success of CSR initiatives include the development of partnerships via public knowledge campaigns, educational programs, technical assistance teams, and engagement with local communities and experts, NGOs, or NPOs.

\section{Discussion and Conclusions}

The Companies Act 2013 introduced a context-specific and culture-sensitive political interpretation of CSR to India. The advantages and disadvantages discussed in this paper illustrate the considerable disagreement by academics on the adequacy of conceptualization and effects of the Act. Our findings are marked by two characteristics: First, that what is considered an advantage in one set of articles is considered a disadvantage in another, emphasizing the challenges associated with how CSR is formulated, appropriated, and implemented in India. The resulting tensions are indicative of the complexities of CSR and the manifold challenges associated with appropriately defining and operationalizing responsibilities for the business sector. It also lays bare the difficulty of connecting CSR to the contexts and cultures within which businesses are embedded. It is therefore unsurprising to find that the academic responses to the Companies Act 2013 emulate the enduring, conflicting debates in the field of CSR. We were struck by the dearth of high-quality empirical evidence associate with the many sweeping statements about the ostensible success or failure of the Companies Act 2013. This also explains the tendency of many authors to either clearly support or criticize the Act—few provided a balanced or complex assessment thereof.

The second defining characteristic relates to the disproportionately high representation of disadvantages in the literature. At first glance, this could be interpreted as an indicator of resistance to the Act. However, despite extensive criticisms, few recommendations are proposed to address its shortcomings. Interestingly, academics do not suggest major adjustments to the Act, nor does anyone propose that it should be rescinded-despite numerous and strong objections to mandating CSR. Instead, most suggestions offer implementation strategies aimed at enhancing the effectiveness 
of the Act. While initial responses may have addressed the inadequacy of the conceptual nature of CSR in the Act, recommendations tend to focus instead on matters of execution. The most recent revision of the Act, adopted on 26 July 2019, indicates that some critiques raised in the literature have been integrated. For example, recommendations to penalize firms that fail to spend their $2 \%$ and that unspent funds automatically be invested in long-term government projects $[56,57,65,84,85,99]$ have now been incorporated.

Any CSR approach ought to be based on the interdependence between business and society, which, accordingly, should emphasize the integration of politics, culture, and context as transversal influences in shaping the responsibilities of business [3]. Economic, social, and environmental concerns, corporate responsibilities, and stakeholder expectations are interdependent. In defining and refining their interdependence from a business perspective, we have stated elsewhere that

Corporate sustainability refers to a systematic business approach and strategy that takes into consideration the long-term social and environmental impact of all economically motivated behaviors of a firm in the interest of consumers, employees, and owners or shareholders. [3] (p. 10)

The Companies Act 2013 has provided a backdrop for an Indian variant of corporate sustainability and, in addition, offers great potential to contribute to a context-specific and culture-sensitive business-society nexus. It formulates the responsibilities of business toward social and environmental goals, while maintaining flexibility in scope and applicability in light of new developments. It not only acknowledges the interdependence between social and environmental concerns, but it also fosters long-term alliances between business, society, and government. As outlined in the Companies Act 2013, CSR activities extend beyond the normative, ethics-based conceptualizations that dominate the international business ethics literature.

Nevertheless, immediate business interests and concerns tend to be neglected in the Act as it emphasizes primarily social development and, to a lesser extent, environmental management. From our perspective, this is a cause for concern. When strengthening the business-society nexus, it is vital that CSR expectations do not oppose economic and business interests but explicitly integrate and embrace them [3]. This is not part of the general gist of the Act. For example, activities associated with employees are largely excluded (i.e., they may not exceed 5\% of the total CSR investments), as is shared value creation as part of a CSR project or program. This is a missed opportunity because benefits to employees and their families may directly and indirectly benefit local communities, regions, and associated businesses. Second, a growing consensus promotes shared value creation as a viable model for developing sustainable and inclusive societies. Many well-known initiatives in finance, agriculture, digitization, and renewable energy have illustrated how such initiatives may drive innovation and enhance leapfrogging. The latter mechanism is especially relevant to emerging market economies as a way to address inequalities and lack of infrastructure. We wonder what the long-term consequences are of excluding activities that would create shared benefits between businesses, communities, employees, and other stakeholders. We fear that separating business practices from the responsibility of business to society may contribute to a mindset, in which firms merely pay their obligatory $2 \%$ share, instead of engaging in a systematic integration of social and environmental concerns as active partners in a shared wealth and wellbeing creation.

Finally, this study contributes in the following ways to our understanding of political CSR. First, as a policy tool to foster a sustainable business-society nexus, the Companies Act 2013 provides a framework to standardize CSR involvement that facilitates development, measurement, monitoring, evaluation, and reporting of social and environmental responsibilities across regions and sectors. As Mahood and colleagues [24] state, this provides an opportunity for government to take control of the CSR agenda and to address social and environmental challenges as part of an increasingly successful business sector. Concurring with Bissoon [30] and Mahmood et al. [24], our findings imply that the Act has the potential to promote sustainable corporate practice, especially in relation to accountability 
and transparency. Future research should examine empirically the actual social and environmental impact of the Companies Act 2013. Second, inclusion and exclusion criteria used to define a policy approach to CSR can have significant consequences on the future sustainability of firms and society alike. The dominance of one domain over another, or the explicit exclusion of business know-how or interests could undermine the long-term impact and effectiveness of the Act. In this regard, it is reassuring to see that the recent revision of the Act seems to indicate the government's responsiveness to some of the shortcomings of previous versions. Finally, the tension between what are considered voluntary or mandatory responsibilities of business reveals an underlying fault line between the two types of political CSR-one variant emphasizing the benefits of voluntary responsibilities of firms, the other favoring a directive and regulatory approach. Our study outlines a third variant of political CSR, which transcends the voluntary versus mandatory divide, or the bottom-up versus top-down mechanisms. This third variant conceptualizes political CSR as complementary to corporate governance [34,35]. Political CSR from this perspective would formulate responsibilities of business in relation to economic, social, and environmental concerns in accordance with political, contextual, and cultural realities for the long-term benefit and wellbeing of business and society. In the long run, economically motivated behaviors of firms need to consider their social and environmental impact, and social and environmental policies need to consider their impact on businesses and the economy. With the Companies Act 2013, India is experimenting with a unique and malleable instrument in a quest to develop an equitable and sustainable business-society nexus.

Author Contributions: All authors contributed equally.

Funding: This research received no external funding.

Conflicts of Interest: The authors declare no conflict of interest.

\section{References}

1. Ministry of Corporate Affairs (MCA). The National Voluntary Guidelines on Social, Environmental and Economic Responsibilities of Business; Ministry of Corporate Affairs (MCA): New Delhi, India, 2011.

2. Bergman, M.M. Linking Business and Society beyond Corporate Responsibility: Culture, Social Development, and Corporate Sustainability. J. Int. Bus. Ethics 2016, 8, 3-8.

3. Bergman, M.M.; Bergman, Z.; Berger, L. An Empirical Exploration, Typology, and Definition of Corporate Sustainability. Sustainability 2017, 9, 753. [CrossRef]

4. Berger, L.; Bergman, M.M.; Bergman, Z.; Leisinger, K.M.; Ojo, E. The Influence of Context and Culture on Corporate Responsibility Expectations in South Africa. J. Int. Bus. Ethics 2014, 7, 3-21.

5. Bergman, M.M.; Leisinger, K.M.; Bergman, Z.; Berger, L. An Analysis of the Conceptual Landscape of Corporate Responsibility in Academia. Bus. Prof. Ethics J. 2015, 34, 165-193. [CrossRef]

6. Cherian, J.; Umar, M.; Thu, P.A.; Nguyen-Trang, T.; Sial, M.S.; Khuong, N.V. Does Corporate Social Responsibility Affect the Financial Performance of the Manufacturing Sector? Evidence from an Emerging Economy. Sustainability 2019, 11, 1182.

7. Elkington, J. Towards the Sustainable Corporation: Win-Win-Win Business Strategies for Sustainable Development. Calif. Manag. Rev. 1994, 36, 90-100. [CrossRef]

8. Frynas, J.G.; Stephens, S. Political Corporate Social Responsibility: Reviewing Theories and Setting New Agendas. Int. J. Manag. Rev. 2015, 17, 483-509. [CrossRef]

9. Blowfield, M.; Frynas, J.G. Setting New Agendas: Critical Perspectives on Corporate Social Responsibility in the Developing World. Int. Aff. 2005, 81, 499-513. [CrossRef]

10. Boddewyn, J.; Doh, J. Global strategy and the collaboration of MNEs, NGOs, and governments for the provisioning of collective goods in emerging markets. Glob. Strategy J. 2011, 1, 345-361. [CrossRef]

11. Carroll, A.B.; Shabana, K.M. The Business Case for Corporate Social Responsibility: A Review of Concepts, Research and Practice. Int. J. Manag. Rev. 2010, 12, 85-105. [CrossRef]

12. Banerjee, S.B. Managerial perceptions of corporate environmentalism: Interpretations from industry and strategic implications for organizations. J. Manag. Stud. 2001, 38, 489-513. [CrossRef] 
13. Jiang, Z.; Wang, Z.; Zeng, Y. Can voluntary environmental regulation promote corporate technological innovation? Bus. Strategy Environ. 2019, 1-17. [CrossRef]

14. Masud, M.D.A.K.; Nurunnabi, M.; Bae, S.M. The effects of corporate governance on environmental sustainability reporting: Empirical evidence from South Asian countries. Asian J. Sustain. Soc. Responsib. 2018, 3, 1-26. [CrossRef]

15. Child, J.; Tsai, T. The Dynamic between Firms' Environmental Strategies and Institutional Constraints in Emerging Economies: Evidence from China and Taiwan. J. Manag. Stud. 2005, 42, 95-125. [CrossRef]

16. Den Hond, F.; Rehbein, K.A.; de Bakker, F.G.A.; Lankveld, H.K. Playing on Two Chessboards: Reputation Effects between Corporate Social Responsibility (CSR) and Corporate Political Activity (CPA). J. Manag. Stud. 2014, 51, 790-813. [CrossRef]

17. Uddin, S.; Siddiqui, J.; Islam, M.A. Corporate Social Responsibility Disclosures, Traditionalism and Politics: A Story from a Traditional Setting. J. Bus. Ethics 2018, 151, 409-428. [CrossRef]

18. Mäkinen, J.; Kourula, A. Pluralism in Political Corporate Social Responsibility. Bus. Ethics Q. 2012, 22, 649-678. [CrossRef]

19. Scherer, A.G.; Palazzo, G. Toward a Political Conception of Corporate Responsibility: Business and Society Seen from a Habermasian Perspective. Acad. Manag. Rev. 2007, 32, 1096-1120. [CrossRef]

20. Scherer, A.G.; Palazzo, G. The New Political Role of Business in a Globalized World: A Review of a New Perspective on CSR and its Implications for the Firm, Governance, and Democracy. J. Manag. Stud. 2011, 48, 899-931. [CrossRef]

21. Aguilera, R.V.; Rupp, D.E.; Williams, C.A.; Ganapathi, J. Putting the S back in corporate social responsibility: A multilevel theory of social change in organizations. AMR 2007, 32, 836-863. [CrossRef]

22. Wickert, C. "Political” Corporate Social Responsibility in Small- and Medium-Sized Enterprises: A Conceptual Framework. Bus. Soc. 2016, 55, 792-824. [CrossRef]

23. Börzel, T.A.; Risse, T. Governance without a state: Can it work? Regul. Gov. 2010, 4, 113-134. [CrossRef]

24. Mahmood, Z.; Kouser, R.; Masud, M.A.K. An emerging economy perspective on corporate sustainability reporting-Main actors' views on the current state of affairs in Pakistan. Asian J. Sustain. Soc. Responsib. 2019, 4, 1-31. [CrossRef]

25. Lawton, T.; McGuire, S.; Rajwani, T. Corporate Political Activity: A Literature Review and Research Agenda. Int. J. Manag. Rev. 2013, 15, 86-105. [CrossRef]

26. Bergman, Z.; Teschemacher, Y.; Arora, B.; Sengupta, R.; Leisinger, K.M.; Bergman, M.M. Developing the business-society nexus through corporate responsibility expectations in India. critical perspectives on international business 2019. Crit. Perspect. Int. Bus. 2019. [CrossRef]

27. Marquis, C.; Qian, C. Corporate Social Responsibility Reporting in China: Symbol or Substance? Organ. Sci. 2013, 25, 127-148. [CrossRef]

28. Lau, C.L.L.; Bergman, Z.; Bergman, M.M. Environmental Protection and Corporate Responsibility: The Perspectives of Senior Managers and CxOs in China. Sustainability 2019, 11, 3610. [CrossRef]

29. Waagstein, P.R. The Mandatory Corporate Social Responsibility in Indonesia: Problems and Implications. J. Bus. Ethics 2011, 98, 455-466. [CrossRef]

30. Bissoon, O. Corporate social responsibility in Mauritius: An analysis of annual reports of multinational hotel groups. AJSSR 2018, 3, 2. [CrossRef]

31. Knudsen, J.S.; Moon, J. Visible Hands: Government Regulation and International Business Responsibility; Cambridge University Press: Cambridge, UK, 2017; ISBN 978-1-107-10490-7.

32. Gulenko, M. Mandatory CSR reporting-Literature review and future developments in Germany. NachhaltigkeitsManagementForum 2018, 26, 3-17. [CrossRef]

33. Uwer, D.; Schramm, M. The Transposition of the CSR Directive into German Commercial Law. PA Persona e Ammin. 2018, 197-221. [CrossRef]

34. Cormier, D.; Lapointe-Antunes, P.; Magnan, M. Does corporate governance enhance the appreciation of mandatory environmental disclosure by financial markets? J. Manag. Gov. 2015, 19, 897-925. [CrossRef]

35. Moon, J. The Social Responsibility of Business and New Governance 1. Gov. Oppos. 2002, 37, 385-408. [CrossRef]

36. World Bank. India GDP Growth (Annual \%)|Data 2018. Available online: https://data.worldbank.org/ indicator/NY.GDP.MKTP.KD.ZG?locations=IN (accessed on 27 June 2019). 
37. International Monetary Fund. World Economic Outlook Update. An Update of the Key WEO Projections 2017. Available online: http://www.imf.org/external/pubs/ft/weo/2017/update/01/pdf/0117.pdf (accessed on 4 July 2019).

38. Fortune Global 500. Fortune India 2016. Available online: https://www.fortuneindia.com/fortune-500?year= 2016 (accessed on 1 July 2019).

39. Fortune Global 500. Fortune India 2017. Available online: https://www.fortuneindia.com/fortune-500?year= 2017 (accessed on 1 July 2019).

40. Fortune Global 500. Fortune India 2018. Available online: https://www.fortuneindia.com/fortune-500?year= 2018 (accessed on 1 July 2019).

41. CEIC Data India Foreign Direct Investment: 1990-2019. Available online: https://www.ceicdata.com/en/ indicator/india/foreign-direct-investment (accessed on 1 July 2019).

42. World Bank. India's Poverty Profile 2016. Available online: https://www.worldbank.org/en/news/infographic/ 2016/05/27/india-s-poverty-profile (accessed on 27 June 2019).

43. Oxfam. The Commitment to Reducing Inequality Index 2018. Available online: https://www.oxfam.org/en/ research/commitment-reducing-inequality-index-2018 (accessed on 2 July 2019).

44. World Bank. Population Living in Slums (\% of Urban Population). Available online: https://data.worldbank. org/indicator/EN.POP.SLUM.UR.ZS?view=chart (accessed on 2 July 2019).

45. Kumar, N. Corporate Social Responsibility and Its Position in India. Glob. Acad. Res. J. 2015, 3, 4-12.

46. Kumar, N. Corporate Social Responsibility: An Analysis of Impact and Challenges in India. Abhinav-Int. Mon. Refereed J. Res. Manag. Technol. 2014, 3, 97-104.

47. Vijayalatha, S.; Brindha, D.G. Emerging Trends and Challenges in Corporate Social Responsibility- India. Int. J. Innov. Res. Sci. Eng. Technol. 2015, 4, 8953-8960.

48. Ali, S.; Hussain, T.; Zhang, G.; Nurunnabi, M.; Li, B. The Implementation of Sustainable Development Goals in "BRICS" Countries. Sustainability 2018, 10, 2513. [CrossRef]

49. Ministry of Corporate Affairs (MCA). Companies Act. 2013. Available online: http://www.mca.gov.in/ Ministry/pdf/CompaniesAct2013.pdf (accessed on 27 June 2019).

50. Ministry of Law and Justice. The Companies (Amendment) Act. 2019. Available online: http://www.mca. gov.in/Ministry/pdf/AMENDMENTACT_01082019.pdf (accessed on 27 June 2019).

51. Afsharipour, A.; Rana, S. The Emergence of New Corporate Social Responsibility Regimes in China and India. UC Davis Bus. Law J. 2014, 14, 175-230.

52. Agrawal, S.; Singh, R. Corporate Social Responsibility for Social Impact: Approach to Measure Social Impact Using CSR Impact Index; Indian Institute of Management Calcutta: Calcutta, India, 2013; pp. 1-8.

53. Ambasta, A. ITC Limited's Mission SunehraKal: Two Decades of Transforming Lives and Landscapes. In Corporate Social Responsibility in India: Cases and Developments after the Legal Mandate; Mitra, N., Schmidpeter, R., Eds.; CSR, Sustainability, Ethics \& Governance; Springer International Publishing: Berlin/Heidelberg, Germany, 2017; pp. 97-116, ISBN 978-3-319-41780-6.

54. Araskumar, M.R. Corporate Social Responsibility: Issues and Challenges. Int. Educ. Sci. Res. J. IESRJ 2016, 2, 77-79.

55. Balasubramanian, N. Strengthening Corporate Governance in India; Indian Institute of Management Ahmendabad: Ahmendabad, India, 2014; pp. 1-46.

56. Bansal, S.; Khanna, M.; Sydlowski, J. Incentives for Corporate Social Responsibility in India: Mandate, Peer Pressure and Crowding-Out Effects. Soc. Sci. Res. Netw. 2019, 1-47. [CrossRef]

57. Bird, R.G.; Mukherjee, A.; Duppati, G. Mandatory Corporate Social Responsibility: The India Experience. In Proceedings of the 8th Conference on Financial Markets and Corporate Governance (FMCG), Rochester, NY, USA, 19-21 April 2017; pp. 1-24.

58. Boodoo, M.U. Does Mandatory CSR Reporting Regulation Lead to Improved Corporate Social Performance? Evidence from India; The London School of Economics and Political Science, Department of Management: London, UK, 2016; pp. 1-43.

59. Borman, D.R.; Chakraborty, D. Corporate Social Responsibility in India: A Review of the Indian Companies Act, 2013 with Reference to CSR Provision. Paripex Indian J. Res. 2014, 3, 1-4. [CrossRef]

60. Chatterjee, B.; Mitra, N. CSR Implementation: How Is It Done in India. In Corporate Social Responsibility in India: Cases and Developments after the Legal Mandate; Mitra, N., Schmidpeter, R., Eds.; CSR, Sustainability, Ethics \& Governance; Springer International Publishing: Cham, Switzerland, 2017; pp. 71-77, ISBN 978-3-319-41780-6. 
61. Chatterjee, B.; Mitra, N. CSR should contribute to the national agenda in emerging economies-The 'Chatterjee Model'. Int. J. Corp. Soc. Responsib. 2017, 2, 1. [CrossRef]

62. Chawak, S.; Dutta, D. Corporate Social Responsibility: Trends and Challenges. Abhinav-Int. Mon. Refereed J. Res. Manag. Technol. 2014, 3, 32-39.

63. Deodhar, S.Y. India's Mandatory CSR, Process of Compliance and Channels of Spending; Indian Institute of Management Ahmendabad: Ahmendabad, India, 2015; pp. 1-13.

64. Deodhar, S.Y. Trapping India's CSR in a Legal Net: Will the Mandatory Trusteeship Contribute to Triple Bottom Line? Vikalpa 2016, 41, 267-274. [CrossRef]

65. Deogharkar, H.; Datkhile, S. Implication of Corporate Social Responsibility under Companies Act 2013. Abhinav-Int. Mon. Refereed J. Res. Manag. Technol. 2014, 3, 88-93.

66. Desai, N.; Pingali, V.; Tripathy, A. Is 2\% the Solution? Experimental Evidence on the New CSR Rule in India; Indian Institute of Management Ahmendabad: Ahmendabad, India, 2015; pp. 1-22.

67. Deswal, V. Corporates as socially responsible citizens: A study on the present status of socially responsible behavior of corporates in India and other nations. Int. J. Appl. Res. 2015, 1, 55-57.

68. Dharmapala, D.; Khanna, V. The impact of mandated corporate social responsibility: Evidence from India's Companies Act of 2013. Int. Rev. Law Econ. 2018, 56, 92-104. [CrossRef]

69. Gatti, L.; Vishwanath, B.; Seele, P.; Cottier, B. Are We Moving Beyond Voluntary CSR? Exploring Theoretical and Managerial Implications of Mandatory CSR Resulting from the New Indian Companies Act. J. Bus. Ethics 2018, 147, 1-2. [CrossRef]

70. Gandhi, K. Corporate Social Responsibility: A Need and Challenge in Reference to India. Int. J. Res. Humanit. Soc. Sci. 2015, 3, 45-49.

71. Gangopadhyay, S. Profiting from CSR. Mandatory Spending on Corporate Social Responsibility Does Not Fit in a Market-Driven Society. 2012. Available online: https://www.business-standard.com/article/opinion/ shubhashis-gangopadhyay-profiting-from-csr-112012800080_1.html (accessed on 24 June 2019).

72. Gangopadhyay, S. CSR, Out of the Box. Mandated Corporate Social Responsibility Hurts Shareholders, Not Firms. 2014. Available online: https://www.business-standard.com/article/opinion/shubhashisgangopadhyay-csr-out-of-the-box-114032101233_1.html (accessed on 24 June 2019).

73. Godfrey, J.; Branigan, E.; Khan, S. Old and New Forms of Giving: Understanding Corporate Philanthropy in India. Voluntas 2017, 28, 672-696. [CrossRef]

74. Gupta, A.D. Implementing Corporate Social Responsibility in India: Issues and the Beyond. In Implementing Corporate Social Responsibility: Indian Perspectives; Ray, S., Raju, S.S., Eds.; Springer: New Delhi, India, 2014; pp. 19-29, ISBN 978-81-322-1652-0.

75. Gupta, A.D. CSR in India: From Rhetoric to Reality and Beyond. In Corporate Social Responsibility in India: Cases and Developments after the Legal Mandate; Mitra, N., Schmidpeter, R., Eds.; CSR, Sustainability, Ethics \& Governance; Springer International Publishing: Cham, Switzerland, 2017; pp. 161-166, ISBN 978-3-319-41780-6.

76. Hung, M.; Shi, J.; Wang, Y. The Effect of Mandatory CSR Disclosure on Information Asymmetry: Evidence from a Quasi-Natural Experiment in China. In Proceedings of the Asian Finance Association (AsFA) 2013 Conference, Nanchang, China, 15-17 July 2013; pp. 1-39.

77. Hussain, A. Corporate Social Responsibility under Companies Act 2013: A welcome step to bridge the welfare gap in India. Int. Res. J. Commer. Law 2015, 2, 48-56.

78. Jain, A. The Mandatory CSR in India: A Boon or Bane. IJAR 2014, 4, 301-303. [CrossRef]

79. Japhet, K.; Tawiah, V.; Benjamin, M. Debate on Mandatory Corporate Social Responsibility. In Proceedings of the Social Science Research Network, Rochester, NY, USA, 20 March 2015; pp. 1-10.

80. Jayaraman, A.; D'souza, V.; Ghoshal, T. NGO-business collaboration following the Indian CSR Bill 2013: Trust-building collaborative social sector partnerships. Dev. Pract. 2018, 28, 831-841. [CrossRef]

81. Jha, B.K.; Singh, R. Corporate Social Responsibility in India. IJHERD 2016, 1, 1-8.

82. Kapoor, G.K.; Dhamija, S. Mandatory CSR Spending-Indian Experience. Emerg. Econ. Stud. 2017, 3, 98-112. [CrossRef]

83. Karnani, A. Mandatory CSR in India: A Bad Proposal (SSIR). Available online: https://ssir.org/articles/entry/ mandatory_csr_in_india_a_bad_proposal (accessed on 24 June 2019).

84. Karthika, S.; Nair, R. Does Mandatory CSR Legislation facilitate Earnings Management? Evidence from India. IJITEE 2019, 8, 2865-2868. 
85. Kausar, H. Corporate Social Responsibility-A Step towards Inclusive Growth. J. Intellect. Stud. Theor. 2016, 3, $627-639$.

86. Khan, A.F.; Akhtar, A. Beyond the Traditional CSR: Towards a Sustainable Agenda. In Corporate Social Responsibility in India: Cases and Developments after the Legal Mandate; Springer: Cham, Switzerland, 2017.

87. Kumar, N. A Study of CSR Rules under Companies Act, 2013. Asian J. Multidiscip. Stud. 2014, 2, $142-146$.

88. Manchiraju, H.; Rajgopal, S. Does Corporate Social Responsibility (CSR) Create Shareholder Value? Evidence from the Indian Companies Act 2013. J. Account. Res. 2017, 55, 1257-1300. [CrossRef]

89. Manner, R. Corporate Governance and Corporate Social Responsibility: The Indian Context. CASIRJ 2018, 9 , 161-175.

90. Mehta, D.; Aggarwal, M. Making Corporate Social Responsibility Mandatory in India- Prospects and Problems. IJRBM 2015, 3, 21-30.

91. Mitra, N.; Schmidtpeter, R. The Why, What and How of the CSR Mandate: The Indian Story. In Corporate Social Responsibility in India: Cases and Developments after the Legal Mandate; Mitra, N., Schmidpeter, R., Eds.; CSR, Sustainability, Ethics \& Governance; Springer International Publishing: Cham, Switzerland, 2017; pp. 1-8, ISBN 978-3-319-41780-6.

92. Mitra, R.; Warshay, N. Policy discourse and mandatory CSR in India. In Development-Oriented Corporate Social Responsibility; Jamali, D., Karam, C., Blowfield, M., Eds.; Greenleaf: Sheffield, UK, 2017; Volume 2, pp. 106-120.

93. Mittal, S. CSR implementation: Who is watching. In CSR in India; Corporate Responsibility Watch; Praxis: New Delhi, India, 2016; pp. 42-45.

94. Pal, C.R. Good Corporate Governance Practice with Special Reference to Indian Companies Act, 2013. Paripex Indian J. Res. 2016, 5, 19-21.

95. Parveen, R. Corporate Social Responsibility: An Analysis of Challenges and Prospects in India. Int. J. Res. 2016, 2, 133-141.

96. Parveen, R. Corporate Social Responsibility: An Analysis of Challenges and Prospects in India. In New Perspectives in Sociology and Allied Fields; Sharma, S.N., Ed.; EduPedia Publications (P) Ltd.: New Delhi, India, 2016; pp. 58-66, ISBN 978-1-5350-6522-1.

97. Patra, P. The companies Act and CSR: The landscape in India. In CSR in India; Corporate Responsibility Watch; Praxis: New Delhi, India, 2016; pp. 34-37.

98. Prabhakar, R.; Mishra, S. A Study of Corporate Social Responsibility in Indian Organization: An-Introspection; Ryerson University: Toronto, ON, Canada, 2013; pp. 1-79.

99. Prasad, D. Companies Act, 2013: Incorporating Stakeholder Theory Approach into the Indian Corporate Law. Statut. Law Rev 2018, 39, 292-302. [CrossRef]

100. Rajeev, P.N.; Kalagnanam, S. India's mandatory CSR policy: Implications and implementation challenges. Int. J. Bus. Gov. Ethics 2017, 12, 90-106. [CrossRef]

101. Ramesh, B.; Mendes, S. Corporate social responsibility: Perspectives in Indian context. Aust. J. Bus. Econ. Stud. 2015, 1, 93-101.

102. Rueth, R. CSR in India-Between Tradition, Cultural Influence, Social Structure, and Economic Growth: A Status Quo Analysis on CSR Engagement in India and a Critical Evaluation of the New CSR Law. In Corporate social responsibility in India: Cases and developments after the legal mandate; Mitra, N., Schmidpeter, R., Eds.; CSR, Sustainability, Ethics \& Governance; Springer International Publishing: Cham, Switzerland, 2017; pp. 21-32, ISBN 978-3-319-41780-6.

103. Sarkar, J.; Sarkar, S. Corporate Social Responsibility in India-An Effort to Bridge the Welfare Gap; Indira Gandhi Institute of Development Research: Mumbai, India, 2015; pp. 1-35.

104. Shafi, M. Role of Corporate Social Responsibility in Indian Higher Education: Issues and Challenges. IJRRCEM 2014, 1, 36-46.

105. Shanthamani, N. Corporate Social Responsibility: Issues and Challenges. IRJBM 2015, 8, 34 .

106. Sharma, A. Key drivers endorsing CSR: A transition from economic to holistic approach. Asian J. Bus. Ethics 2016, 1-2, 165-184. [CrossRef]

107. Sharma, S.K. A 360 degree analysis of Corporate Social Responsibility (CSR) Mandate of the New Companies Act, PDF. Glob. J. Manag. Bus. Stud. 2013, 3, 757-762.

108. Sharma, S. Making CSR Mandatory in India- A Flawed Approach. Int. J. Soc. Sci. Humanit. 2013, 3, $33-35$. [CrossRef] 
109. Sharma, S.K.; Tomar, A. Corporate Social Responsibility and Sustainable Development. J. Indian Res. 2013, 1, 112-114. [CrossRef]

110. Singh, A.; Verma, P. CSR: A New Model of Corporate Social Responsibility in India. IJARBSS 2014, 4, 455-464. [CrossRef]

111. Singh, A.; Verma, P. From Philanthropy to Mandatory CSR: A Journey towards Mandatory Corporate Social Responsibility in India. Int. J. Bus. Manag. Invent. 2014, 3, 72-78.

112. Singh, A.K.; Jha, S. Corporate Social Responsibility (CSR) \& Its Implementation towards Good Governance. Int. J. Sci. Res. Manag. 2015, 3, 3210-3226.

113. Stanford Social Innovation Review A Mandate for Responsibility. SSIR 2014, 12, 11-12.

114. Swathi, P.S. A Study on the Role of Directors in the Realm of Corporate Social Responsibility to ensure Society's Sustainability An Analysis of Companies Act 2013-An Indian Perspective. IJRTBT 2019, 3, 77-84.

115. Tandon, D. Corporate Social Responsibility in India: Present Status and Challenges. Int. J. Multidiscip. Adv. Res. Trends 2016, 3, 36-43.

116. Verma, H.; Selvalakshmi, M.; Jain, N. CSR Stipulations of Companies Act, 2013 and Actual CSR Expenditure by Top Indian Companies Prior To Its Implementation: A Comparative Study. IJSTM 2015, 4, 113-121. [CrossRef]

117. Yesudhas, R. Integrating Child Rights in Business: Beyond the CSR Mandate. In Proceedings of the College of Social Work, Nirmala Niketan, Mumbai, India, 29-30 March 2017; pp. 1-11.

118. Bergman, M.M. Content Configuration Analysis; StudyCube; University of St. Gall: St. Gall, Switzerland, 2011.

119. Bergman, M.M.; Bergman, Z.; Gravett, S. The development and application of the Explanatory Model of School Dysfunctions. South Afr. J. Educ. 2011, 31, 461-474. [CrossRef]

120. Bergman, Z.; Bergman, M.M.; Fernandes, K.; Grossrieder, D.; Schneider, L. The Contribution of UNESCO Chairs toward Achieving the UN Sustainable Development Goals. Sustainability 2018, 10, 4471. [CrossRef]

(C) 2019 by the authors. Licensee MDPI, Basel, Switzerland. This article is an open access article distributed under the terms and conditions of the Creative Commons Attribution (CC BY) license (http://creativecommons.org/licenses/by/4.0/). 